\title{
Domestic violence against seniors in rural areas of West Pomerania, Poland
}

\author{
Sebastian Kołodziejczak ${ }^{1, A-F}$, Albert Terelak ${ }^{1, A-F}$, Marek Bulsa ${ }^{1, E-F}$ \\ ${ }^{1}$ University of Szczecin, Poland \\ A - Research concept and design, B - Collection and/or assembly of data, C - Data analysis and interpretation, \\ $D$ - Writing the article, $E$ - Critical revision of the article, F - Final approval of article \\ Kołodziejczak S, Terelak A, Bulsa M. Domestic violence against seniors in rural areas of West Pomerania, Poland. Ann Agric Environ Med. \\ 2019; 26(1): 92-96. doi: 10.26444/aaem/92208
}

\section{Abstract}

Introduction and objective. The study on domestic violence in rural areas of Western Pomerania (Poland), carried out in October 2017, aimed at determining the scale of domestic violence against the elderly, taking into account its 5 forms: psychological, physical, economic and sexual violence, as well as negligence.

Materials and method. The research concept was implemented with the use of a representative sampling method by means of a questionnaire-based audit interview, and using research tools to measure the social scale of the phenomenon of domestic violence, the victims of which were the elderly from one of the rural communes of Western Pomerania.

Results. The basic results of the survey were as follows: 1) $40.1 \%$ of seniors reported experiencing violence from their family members; 2) 36.5\% experienced psychological violence and $21.9 \%$ - negligence; 3 ) $8.8 \%$ were victims of economic violence and $5.1 \%$ - of physical violence; 4 ) sexual abuse was the least frequently reported $-0.7 \%$.

Conclusions. Domestic violence in rural areas could affect as many as $40 \%$ of seniors. Generally, they admitted to experiencing one of the 5 forms of violence distinguished in the study, of which acts of psychological violence were predominant. Negligence and economic violence were relatively less frequent. Physical violence was even less prevalent. On the other hand, $8.1 \%$ of seniors experienced 3-4 forms of violence, which could be considered as a situation of increased risk of pathologisation of their family life.

\section{Key words}

Domestic violence, seniors, elderly, rural areas, physical violence, psychological violence, sexual violence, physical negligence, psychological negligence, overprotection

\section{INTRODUCTION}

There are many definitions of violence in the literature, but it should be stressed that in principle this term is most often used to describe concrete acts, or failures to act, resulting from social expectations related to the role played by the perpetrator towards the victim. The definitions of violence also indicate that an act of violence is directed towards the victim's rights or property (usually their life or health, in the physical and/or mental meaning), thus causing harm and suffering. Typically, violence is defined by reference to various criteria usually related to the extent of harm suffered by the victim, the consequences of violence in various spheres of life, violations of the law and of social norms, and the dynamics of violence experienced by the members of the perpetrators' families [1].

The presented study was based the provisions of the Act of 2005 on counteracting domestic violence which, referring to the domain of 'household - family', defines a family member as:

(...) the next of kin within the meaning of Article $115 \$ 11$ of the Act of 6 June 1997 - The Penal Code (Journal of Laws, No. 88, item 553, as amended) [this refers to a spouse, ascendant, descendant, sibling, relative in the same line or degree, a person undergoing an adoption relationship and his/her spouse, as well as a person sharing a common life], as well as any other cohabitant [2].

Address for correspondence: Sebastian Kołodziejczak Uniwerytet Szczecińki, Twarda 5, 70-751 Szczecin, Poland

e-mail: seb.kolodziejczak@o2.pl

Received: 26.04.2018; accepted: 12.06.2018; first published: 26.06.2018
Domestic violence is defined as:

(...) a single or repeated intentional act or omission which infringes the rights or personal interests of any of the persons mentioned in point 1 , in particular those that endanger their life and health, violate their dignity, physical integrity, freedom, including sexual freedom, thus causing damage to their physical or mental health, as well as causing suffering and moral harm to persons affected by violence [3].

Domestic violence is a complex phenomenon, with the most common forms in literature being the following:

- physical violence - which includes non-accidental injuries suffered as a result of the actions of the perpetrator having emotional closeness with the victim. The use of various forms of coercion, based on the possession and use of physical advantage, to induce decisions and actions that are unwelcome and abusive to the victim;

- psychological violence - all forms of humiliation, including deprivation of victims of their independence, isolation and imposition of the perpetrator's own opinions; deprivation of means necessary for proper functioning in the mental and physical dimension;

- sexual violence - sexual abuse, including rape (also marital rape);

- physical negligence - deprivation of the victim of appropriate care, including necessary medical care. This particularly refers to dependent people (minor children, elderly people, people with disabilities or conditions of illness and needing care); 
- psychological negligence - various forms of emotional rejection, emotional coolness, indifference, avoidance of showing positive feelings, disregard for the victim's psychological and emotional needs;

- overprotection - actions taken by the perpetrator aimed at limiting the proper development of the victim through the use of various forms of excessive control and care. Such actions may lead to impairment of proper psychophysical development and lead to mental and physical harm to the victim [4].

In the presented study, the following forms of domestic violence were subjected to operationalisation: mental violence, physical violence, economic violence, sexual violence and negligence, i.e. harmfully leading to the non-performance of an obligation resulting from the social role performed by the perpetrator towards the victim. At the stage of research reconnaissance, in Individual In-depth Interviews, several dozen formulations were described on the subject of acts of domestic violence, understood as indicators of the phenomenon. Next, using the Focus Group Interview technique, a set of those which are characterized by the highest accuracy and placed on a scale in an ascending order was selected. In this way, 16 indicators accepted for the study was obtained, the empirical validity and reliability of which were verified in 3 pilot studies.

\section{OBJECTIVE}

The research was aimed at determining the scale of domestic violence against seniors in one of the rural communities of Western Pomerania, with reference to 5 forms of domestic violence (mental, physical, negligence, economic and sexual). The questionnaire was developed to measure the scale of particular forms of domestic violence in 3 dimensions of respondents' social lives: 1) in their own personal experience (when they experienced abuse from relatives); 2) in their observations and indirect experience (when one of their family members suffered abuse from relatives).

Adopting such a spectrum of perception led to 2 types of insight:

1) knowledge of an in-depth nature relating not only to the extent of domestic violence against children and young people, but also to the complexity of the problem of domestic violence;

2) knowledge of a cumulative nature resulting from the fact that the declarations of respondents in surveys on harm suffered by members of their families from other household members or close or distant relatives, broaden the picture of the scale of domestic violence in the area covered by the research.

The current study focuses on the research findings concerning the personal experiences of seniors, and falls mainly within the scope of the so-called descriptive goal [5] of empirical research, which is a sine qua non condition for the diagnosis of the phenomenon being examined.

\section{MATERIALS AND METHOD}

The research concept was implemented with the use of a representative sampling method by means of a questionnaire- based audit interview, and using research tools to measure the social scale of the phenomenon of domestic violence, the victims of which are senior citizens. The survey was conducted on a sample of 137 elderly people (represented in the survey by those residents of the area who were active in rural day centres, mainly in seniors' clubs), which accounts for $10.8 \%$ of all senior population living in local society. $85.4 \%$ of the sample were women, and average age of respondents -64.4 years. All levels of education were represented in the realized sample: primary $-28.5 \%$, secondary $-61.3 \%$ and higher $-3.6 \%$ ).

Respondents to the study were asked to indicate whether and how often they had experienced specific examples of domestic violence in the 6 months preceding the study and, if so, further in the past.

\section{RESULTS}

The results of the study show that a total of $40.1 \%$ of the seniors who participated in the study experienced domestic violence. The majority experienced a single form of violence (19\%), and the percentage of interviewees declaring to be victims of more than one form of violence gradually decreased. There was not a single case of a person having experienced all 5 forms of violence at the same time. Assuming that the presence of at least 3 types of domestic violence indicated that there was an atmosphere of accumulated violence within the family, a conclusion can be drawn that $8.1 \%$ of the respondents were affected by domestic violence.

Of the more than $40 \%$ of senior citizens in the area who reported having experienced domestic violence, this figure of more than $8 \%$ may be regarded as a category requiring particular attention from the institutionalised social control (such as the Interdisciplinary Panel for the Prevention of Family Violence) [6]. The coexistence in the family environment of 3 or more forms of violence against seniors should be treated as a situation of a specific accumulation of conditions conducive to the pathologisation of family life, that is a threat to the health or even to the life of not only those victims of violence, but also of other members of their families.

The structure of the sample of the seniors experiencing one or more forms of domestic violence is presented in the chart below.

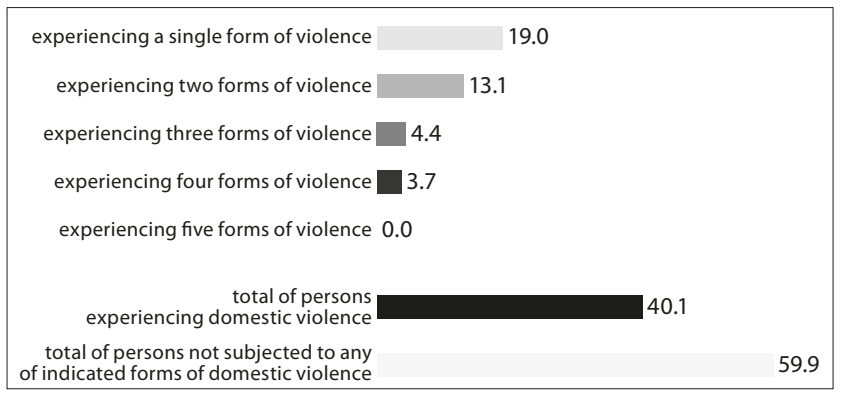

Figure 1. Number of forms of domestic violence experienced by seniors. Data expressed in $\% ; n=137=100 \%$ Source: own survey

A more comprehensive perspective on the structure of the scale of domestic violence against seniors is provided by the chart below. The chart shows the experience of particular forms of domestic violence by their number. 


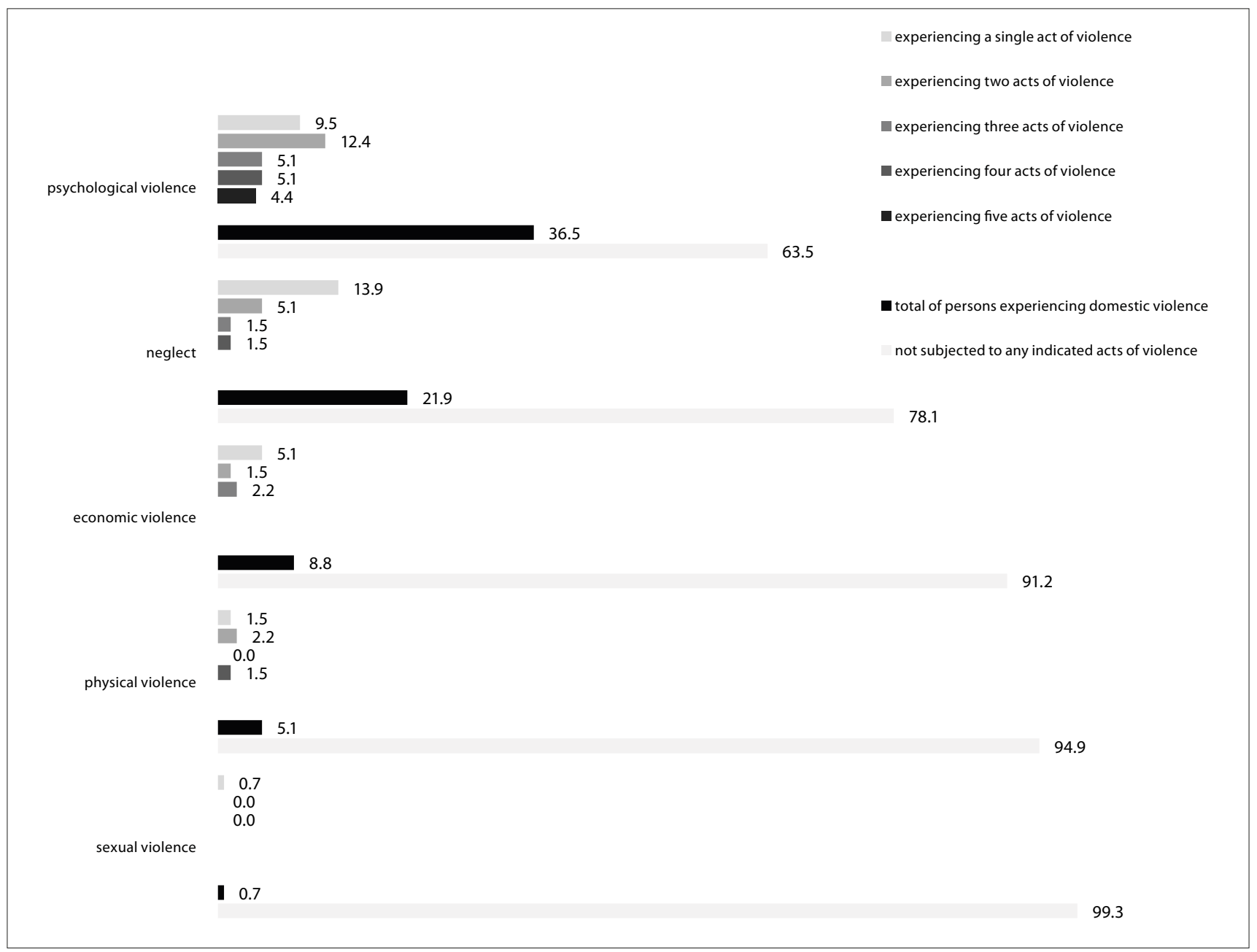

Figure 2. Scale of 5 forms of domestic violence experienced by senior citizens. Data expressed in \%; $n=137=100 \%$ Source: own survey

As reported by participants in the survey, the most frequent was psychological violence experienced by more than one in 3 senior citizens (36.5\%). Mainly mentioned was being blamed for even small defeats/failures. Repeated blaming by another family member for their own failures, at least once in the last 6 months was experienced by $24.1 \%$ of the respondents. At the same time, $67.9 \%$ never experienced such a situation, and $8 \%$ admitted that such situations had not occurred recently, although they had taken place earlier than in the last 6 months. Every fifth respondent (20.4\%) admitted that they had experienced (at different intervals) harmful criticism in their home environment over the past 6 months. For $15.3 \%$ of the participants, it was a multiple experience over that period, and $5.1 \%$ of the respondents experienced such criticism once. It is also worth noting that $6.6 \%$ of the respondents declared to have been victims of unfair criticism earlier than in the 6 months preceding the survey. Submission induced by shouting was experienced by a total of $11.68 \%$, with $8.3 \%$ admitting that it took place within the last 6 months. $19 \%$ of the respondents experienced insults and vulgar remarks addressed to them by a family members at least once in the previous 6 months. $3.7 \%$ had been victims of that type of behaviour earlier. The least frequent acts of domestic psychological violence were those involving humiliation, persistent mocking or ridicule of the elderly. $81.8 \%$ of respondents never experienced such behaviour from their close relatives. However, a total of $6.6 \%$ of the survey participants experienced that at least once in the preceding 6 months.

The second most common form of violence experienced by seniors in the home environment was negligence which affected more than one in 5 interviewees $(21.9 \%)$. The most common type of negligent behaviour acknowledged by elderly people was ignoring their well-being/health, or negligence in providing care when ill. In the 6 months before the survey this was the experience of fewer than one in 10 respondents (10.22\%), and almost 3\% admitted that they had been subject of similar abuse previously. The second most frequent indicator was disinterest in problems and/or ignoring the respondent's feelings/depreciating emotions experienced by $7.3 \%$ of the respondents in their home environments. Additionally, $4.38 \%$ had experienced such treatment earlier than in the preceding 6 months. 3.65\% of the survey participants reported that family members did not provide them with the necessary medical assistance when they needed it.

$8.8 \%$ of the survey participants declared that they were victims of economic violence. In the 6 months preceding the survey, $3.65 \%$ of seniors experienced excessive, persistent control over their expenses by other household members. 
Moreover, $1.46 \%$ declared that such situations had occurred before. $2.92 \%$ of the respondents admitted to have been forced to hand over their money. Relatively often, domestic economic violence against the elderly took the form of a refusal to provide for their satisfiable needs. A total of $5.11 \%$ of the interviewees had experienced such a situation in the preceding 6 months, and one person admitted that they had experienced such an abuse earlier.

Individual experience of physical domestic violence was reported by survey participants significantly less frequently than domestic negligence and domestic psychological and economic violence. A total of $5.1 \%$ of senior citizens admitted to experiencing it. The most common acts of domestic physical violence against seniors included nudging or pushing, etc., e.g. forced to hurry. This behaviour was experienced by $2.19 \%$ of the respondents in the 6 months preceding the survey, and the same number of respondents admitted that such situations had not occurred recently, but earlier. Two interviewees (1.46\%) experienced being beaten with a tool that had not left any visible and permanent traces on their body, and one person (0.73\%) had experienced it earlier. Physical abuse resulting in visible bruises or wounds during the previous 6 months was acknowledged by 2 people (1.46\%), and one $(0.73 \%)$ admitted to experiencing a similar assault earlier. Acts of domestic physical violence in a form of beating, or a few hand slapss and/or kicks, etc., were experienced by 2 people (1.46\%) over the past 2 quarters, and 2 others revealed that they had been victims to this type of abuse before.

One of the forms of domestic violence most difficult to identify is sexual abuse. As far as such acts in a domestic environment directed against seniors in the area under study are concerned, the collected empirical evidence revealed a minor scale of this type of violence. Only one person revealed that once in the preceding 6 months she had been the victim of verbal sexual harassment by her husband.

Another important perspective in described research is the issue of the relationship between the gender of seniors and the forms of domestic violence experienced by them. The research showed a significant disproportion in the number of respondents due to their gender, which made it impossible to estimate a statistically significant relationship between gender and forms of domestic violence. Another context of this issue revealed respondents' indications on members of their families experiencing domestic violence. They show that victims are more often women than men, and in the case of psychological violence, this advantage is more than 2-fold (women who experience domestic violence indicated a total of $21.5 \%$ of participants, men $-10.7 \%$ ). However, this issue requires further, in-depth studies.

\section{DISCUSSION}

Researchers' interest in violence against the elderly, including domestic violence, dates back at least to the 1980s when the US National Committee for the Prevention of Elder Abuse was established. The World Report on Violence and Health [10], prepared in 2002 by the World Health Organisation, contained a whole chapter focusing on the problem of violence and abuse against the elderly, which contributed to publicising the problem and initiating research in many countries. The research projects resulted in a number of findings concerning the scale of the problem, stating that it concerns from $4 \%$ to just over $20 \%$ of people over the age of 60 [6]. In Poland, the issue of domestic violence against seniors has so far been the subject of a relatively small number of studies. It should be emphasized that there is a lack of, above all, in-depth analyses and a detailed description of the characteristics of the phenomenon [14]. The results of research conducted in 2009 and 2015 by the Polish Academy of Sciences on representative nationwide samples of people aged 18 and over show that, depending on the form of violence, a maximum of one in 5 respondents reported cases of domestic violence against seniors. The 2015 survey most frequently reported cases of psychological violence $-20.5 \%$ observed outside the respondent's own family and $7.5 \%$ in the respondent's family as well as economic violence $-19.7 \%$ outside the family and $8.3 \%$ in the respondent's family. Cases of domestic physical violence against elderly people were reported less frequently - $13.9 \%$ outside the respondent's family and $5.8 \%$ within the family, while sexual violence outside the family was experienced by $3.1 \%$ of respondents and in $2.4 \%$ of cases - within the respondent's family. The category of 'negligence' was not specified in these studies [7]. In contrast, in the presented study, it is an important form of violence due to the fact that it is identified as a component of discrimination on the basis of age (ageism), which is a research trend that provides a significant perspective on the phenomenon of domestic violence as a whole $[11,12,13]$.

The findings concerning the distribution of forms and the incidence of experience of domestic violence resulting from the present survey conducted among senior citizens of rural areas of West Pomerania, show that domestic violence probably affects $40.1 \%$ of elderly people, with the highest incidence of psychological violence (36.5\%) and negligence (21.9\%), which is several times higher than in the case of economic (8.8\%) and physical (5.1\%) violence. It is clear from the study that psychological violence, negligence and economic violence are prevalent, while physical abuse and sexual abuse are less frequent.

It seems justified to carry out the research in the isolated categories of respondents, because the cross-sectional research, even if carried on large samples (representative for the whole population) may distort the vision of the problem. Results of surveys conducted simultaneously among schoolchildren from the same rural areas (on the sample of 380 respondents, constituting $46.7 \%$ of the population of schoolchildren and adolescents aged over 10 in the area of research) showed that, similar to seniors, psychological violence was the most common (42.4\%), followed by negligence $(21.1 \%)$. In contrast to seniors, physical violence in young interviewees' families was more frequent (17.1\%) than economic violence (17.1\%) [8].

\section{CONCLUSIONS}

- $40.1 \%$ of the population of seniors from the rural area covered by the survey experienced some form of violence in their domestic environment;

- $8.1 \%$ of seniors experienced 3-4 forms of violence, which could be considered as a situation of increased risk of pathologisation of their family life;

- the most common form of violence was psychological violence, reported by $36.5 \%$ of the respondents; 
- abuse qualified as negligence (21.9\%) and economic violence $(8.8 \%)$ were more common than physical violence $(5.1 \%)$;

- sexual violence was negligible at $0.7 \%$.

\section{REFERENCES}

1. Por. Widera-Wysoczańska A. Mechanizmy przemocy w rodzinie. Z pokolenia na pokolenie, Difin SA, Warszawa 2010; 28 (in Polish).

2. Ustawa z dnia 29 lipca 2005 r. o przeciwdziałaniu przemocy w rodzinie (Dz. U. Nr 180, poz. 1493), art. 2, item 1

3. Ibidem, art. 2, item 2

4. Por. Mazur J. Przemoc w rodzinie. Teoria i rzeczywistość, „Żak”, Warszawa 2002; 40 (in Polish).

5. Por. Sołoma L. Metody i techniki badań socjologicznych: wybrane zagadnienia, Uniwersytet Warmińsko-Mazurski, Olsztyn 1999; 8 (in Polish).

6. Halicka M. Ludzie starzy jako ofiary przemocy, in: Szukalski P, Szatur-Jaworska B. (editors), Aktywne starzenie się - przeciwdziałanie barierom, Uniwersytet Łódzki, Łódź 2014; 91 (in Polish).

7. Korzeniowski K, Radkiewicz P. Przemoc w rodzinie wobec osób starszych i niepełnosprawnych. Raport z badania ogólnopolskiego 2015 r. oraz badania porównawczego z lat 2009-2015, Polska Akademia Nauk, Warszawa 2015, 32-35 (in Polish).
8. Terelak A, Kołodziejczak S. Skala zjawiska przemocy w rodzinie wobec uczniów, seniorów oraz osób niepełnosprawnych z terenu gminy Darłowo. Przemoc domowa w codziennych doświadczeniach i obserwacji osób starszych oraz uczniów szkół gminy. Na podstawie analizy danych z autorskich badań socjologicznych w zakresie rozpoznania skali zjawiska przemocy w rodzinie wobec seniorów, osób niepełnosprawnych, dzieci i młodzieży na obszarze gminy Darłowo, Raport z badań, Szczecin 2017 (in Polish).

9. Kiełb-Grabarczyk D. Ludzie starzy jako osoby doznające przemocy i jako jej sprawcy, in: Wirkus Ł., Kozłowski P. (editors), Przemoc w rodzinie - ujęcie interdyscyplinarne, Impuls, Kraków 2017, 161-181 (in Polish).

10. Krug EG, Dahlberg LL, Mercy JA, Zwi AB, Lozano R. (eds.). 2002, World report on violence and health, World Health Organization, Geneva (http://www.who.int/violence_injury_prevention/violence/ world_report/en/index.html)

11. Szukalski P. Ageizm - dyskryminacja ze względu na wiek. In: Jerzy T. Kowaleski, Piotr Szukalski editors, Starzenie się ludności Polski między demografią a gerontologią społeczną, Wyd. UŁ, Łódź 2008, p. 153-184 (in Polish).

12. Świderska M. Ageizm jako problem społeczny, Pedagogika Rodziny. Family Pedagogy 2015; 5(4): 41-50 (in Polish).

13. Levy BR, Banaji MR. Implicit ageism. In: Nelson T, editor. Ageism: stereotypes and prejudice against older persons., MIT Press, Cambridge 2002 . 